\title{
INVOLVEMENT OF THE CENTRAL NERVOUS SYSTEM IN DENGUE FEVER: THREE SEROLOGICALLY CONFIRMED CASES FROM FORTALEZA, CEARÁ, BRAZIL
}

\author{
Pedro F. C. vasconcelos(1), Amélia P. A. TRAVASSOS Da ROSA(1), Ivo C. B. COELHO(2), Dalgimar B. MENEZES(3), Elizabeth S. TRAVASSOS DA \\ ROSA(1), Sueli G. RODRIGUES(1) \& Jorge F. S. TRAVASSOS DA ROSA(1)
}

\begin{abstract}
SUMMARY
Three cases of dengue fever involving the central nervous system (CNS) are reported. All occurred in 1994 during a dengue (DEN) epidemic caused by serotypes DEN-1 and DEN-2. The first case examined was a 17-year-old girl who complained of fever, nuchal rigidity and genital bleeding. Three blood samples were positive by anti-dengue IgM ELISA and showed hemagglutination-inhibition (HI) test titers $\geq 1,280$. The second case concerned a 86-year-old woman with fever, muscle and joint pains, altered consciousness, syncope, nuchal rigidity and meningismus. Her blood sample showed an HI titer of 1:320 for flaviviruses, and an IgM ELISA positive for dengue. The third case was a 67-year-old woman with fever, abnormal behaviour, seizures, tremor of extremities, thrombocytopenia, increased hematocrit and leukopenia. The patient suffered a typical case of dengue hemorrhagic fever with ensuing shock and a fatal outcome. A single blood sample showed $\mathrm{HI}$ antibodies of $\geq 1,280$ and an IgM ELISA positive for dengue. No virus could be isolated from any patient by inoculation of blood into $\mathrm{C} 6 / 36$ cells and suckling mice. No other agent of disease was encountered in the patient.
\end{abstract}

KEYWORDS: Dengue; Dengue IgM; CNS involvement; Encephalitis.

\section{INTRODUCTION}

Dengue fever (DF) and dengue hemorrhagic fever (DHF) are among the most important of the arthropod-borne diseases, and are caused by dengue (DEN) virus serotypes 1-4. This Flavivirus (family Flaviviridae) is transmitted to man by the hematophagous mosquito Aedes aegypti, a domesticperidomestic insect. Man is the major vertebrate host and is the most important means of dispersion of the illness. To date, only this mosquito species has been associated with viral transmission in Brazil, despite the presence of Aedes albopictus, a competent vector in Asia (WHO, 1986).

From 1986 to 1993, the State of Ceará in the Northeast region of Brazil has suffered both outbreaks and large epidemics, all caused by DEN-1. The number of cases reported in the period was 53,593 and accounted for $15.9 \%$ of all notified cases of Brazilian dengue. No cases of DHF were reported. In 1994, an outbreak of DEN-2 caused the most severe and extensive dengue epidemic known from the region. Thousands of cases were reported and at least 26 cases of DHF were confirmed and notified; of these, 14 had a fatal outcome (VASCONCELOS et al., 1995). A random sero-epidemiological survey carried out in the capital, Fortaleza, and the area most affected by the epidemic, estimated the infection to afflict 600,000 people (VASCONCELOS et al., submitted).

Recent reports have mentioned patients exhibiting involvement of the central nervous system (CNS). It is not clear whether such involvement is caused by the direct action of the DEN virus (PATEY et al., 1993; LUM et al., 1996; ROW et al., 1996). However, CHIMELLI et al. (1990) have demonstrated the occurrence of nonspecific microscopic neurological alterations, including congested leptomeninges, cortical anoxic changes, congestion, edema, and small perivascular hemorrhagic foci in five patients with fatal dengue from Niterói, Brazil, during the 1987 DEN-1 epidemic. It is noteworthy that, in one case, perivenous encephalitis was found.

The present study reports three cases of patients who developed an unusual manifestation in which there was a notable involvement of the CNS. All were confirmed by specific laboratory examination.

(1) WHO Collaborating Center for Arbovirus Reference and Research. Instituto Evandro Chagas, Av. Almirante Barroso 492, 66090-000, Belém, PA, Brasil.

(2) Núcleo de Medicina Tropical. Universidade Federal do Ceará, Fortaleza, CE, Brasil.

(3) Departamento de Patologia. Universidade Federal do Ceará, Fortaleza, CE, Brasil.

Correspondence to: Dr. Pedro Fernando da Costa Vasconcelos. Áv. Ảimirante Barroso 492, 6́ó90-000, Belémi, PA, Brazil. 
VASCONCELOS, P. F. C.; TRAVASSOS DA ROSA, A. P. A.; COELHO, I. C. B.; MENEZES, D. B.; TRAVASSOS DA ROSA, E. S.; RODRIGUES, S. G. \& TRAVASSOS DA

ROSA, J. F. S. - Involvement of the central nervous system in dengue fever: three serologically confirmed cases from Fortaleza, Ceará, Brazil. Rev. Inst. Med. trop. S. Paulo, 40(1):35-39, 1998

\section{MATERIAL AND METHODS}

Patients: All patients were hospitalized. Two were admitted to the Hospital Antonio Prudente and one to the Hospital Gastroclínica, Fortaleza (CE).

Serology: For DEN diagnosis, two serological tests are routinely performed at the Instituto Evandro Chagas: a hemagglutination-inhibition test (HI), using a microtechnique (SHOPE, 1963) against antigens from the DEN-1, DEN-2, DEN3 and DEN-4, Ilhéus, Rocio, Saint Louis encaphalitis (SLE) and Yellow fever viruses; and an IgM ELISA capture test (KUNO et al., 1987). The HI test can differentiate primary response (PR) titers below 1:1,280, and is relatively monospecific, from the secondary response (SR) with titers above 1:2,560, for all antigens tested, according to World Health Organization criteria (WHO, 1986). The IgM capture technique is tested with Dengue 1 and 2 , and Yellow fever antigens.

To determine the etiology of the present cases, the NT was performed in suckling mice using the main flaviviruses associated with the human disease in Brazil, namely, the Yellow fever, SLE, DEN-1 and DEN-2 viruses. A ten fold, serial dilution of the virus, and a fixed (1:8) dilution of the serum samples were used. The logarithmic neutralization index $(\log \mathrm{NI})$ was calculated using the Reed \& Muench method (BEATY et al., 1989).

Virus isolation: Attempts to isolate the virus were made by inoculating a 1:10 diluted blood suspension into cloned $\mathrm{C} 6 / 36$ Aedes albopictus cells (TESH, 1979), and by intracranial inoculation in baby Swiss mice (BEATY et al., 1989).

\section{RESULTS}

Case 1 (H 527807 - CEA 2448). A 17-year-old woman residing in Fortaleza, reported the abrupt onset of illness on June 16 , characterized by fever, headache, nausea and abdominal pain. Blood pressure was $120 \times 80 \mathrm{mmHg}$, and the hematocrit $36 \%$. The patient was kept in ambulatorial follow-up. Four days later, a macular erythematous skin rash, epistaxis and bleeding gums were observed. At this point, the patient was hospitalized.

At admission, on June 20, in addition to the above symptoms, the patient presented genital bleeding, photophobia, nuchal rigidity, Kernig's sign, right hemiparesis with loss of sensitivity, and uncoordinated movements. Blood pressure dropped to $80 \times 40 \mathrm{mmHg}$; the white cell count was 5,900 (lymphocytes 54\%, monocytes $11 \%$, and neutrophils $35 \%$ ), the hematocrit reading was $36 \%$, and platelets ranged from 135,000 ( $4^{\text {th }}$ day after onset) to 245,000 ( $11^{\text {th }}$ day after onset $)$. The complete examinations are shown in Table 1.

Three serum samples, taken on the $5^{\text {th }}, 9^{\text {th }}$ and $10^{\text {th }}$ days after onset of symptoms, were inoculated into C6/36 cells and into mouse brain, but no virus could be isolated. By HI these same serum samples reached titers $\geq 1280$ for all dengue serotypes and the other flaviviruses tested (Yellow fever-ME, St. Louis encephalitis-SLE, Ilheus-ILH, and Rocio-ROC). By ELISA, all three samples were positive for anti-dengue $\operatorname{IgM}$ only. Seven days later, the patient recovered, without sequelae. Screening for hepatitis $A$ and $B$ viruses and leptospirosis was negative. NT performed with the serum samples neutralized the SLE (2.9 $\log \mathrm{NI})$ and DEN-1 (2.4 log NI) viruses.

Case 2 (H 527809 - CEA 2450). An 86-year-old woman arrived from Caucaia, a small town in the metropolitan area of Fortaleza city, Ceará, Brazil. The principal symptoms observed were an acute febrile illness, muscle and joint pains, and dizziness. The symptoms persisted for nine days, after which the patient was hospitalized on June 20, owing to an episode of altered consciousness (syncope). At the time of hospitalization the patient complained of severe headache with nuchal rigidity. Physical examination showed mild meningism without neurological deficiency or altered consciousness. The cerebrospinal fluid (CSF) was clear and no cells were found. Blood pressure on admission was $130 \times 80 \mathrm{mmHg}$. The white cell count showed leukopenia (3,600 leukocytes), and hematocrit of $28 \%$. On the following day (June 21), an episode of epistaxis was observed; blood pressure was $140 \times 80 \mathrm{mmHg}$. Over the following three days, the patient felt better and recovery was uneventful. A blood sample taken on admission (ninth day of illness), showed a negative result after inoculation into C6/36 cells and mouse brain; however, the ELISA test for dengue specific $\operatorname{IgM}$ antibodies was positive. The HI titers of DEN-1 and DEN-2 were 320; of DEN-3 and DEN-4 160; of YF and SLE 640; and of ROC and of ILH 160. The NT for this sample neutralized only the DEN-1 virus $(2.1 \log \mathrm{NI})$.

Case 3 (H 527845 - CEA 2482). A 67-year-old woman, from Fortaleza, reported an acute illness on June 3, characterized by an abrupt onset with fever, headache, motor incoordination

TABLE 1

Results of the principal laboratory findings and blood pressure for case 1 .

\begin{tabular}{|c|c|c|c|c|c|}
\hline Parameter & $\begin{array}{c}\text { Days } \\
4^{\text {th }}\end{array}$ & $\begin{array}{c}\text { After } \\
5^{\text {th }}\end{array}$ & $\begin{array}{c}\text { Onset } \\
6^{\text {th }}\end{array}$ & $\begin{array}{l}\text { Of } \\
9^{\text {th }}\end{array}$ & $\begin{array}{c}\text { Symptoms } \\
11^{\text {th }}\end{array}$ \\
\hline Hematocrit (\%) & 36 & 37.4 & 33.2 & 35 & 38 \\
\hline Platelets (x 1,000) & 135 & 145 & 200 & 220 & 245 \\
\hline Leukocytes (per ml) & NA & NA & 5,900 & NA & NA \\
\hline Blood pressure $(\mathrm{mm} \mathrm{Hg})$ & $120 \times 80$ & NA & $100 \times 60$ & $80 \times 40$ & $120 \times 80$ \\
\hline
\end{tabular}

NA: Not available. 
TABLE 2

Results of the principal laboratory findings for case 3.

\begin{tabular}{lccc}
\hline Parameter & $1^{\text {st }}$ day & $2^{\text {nd }}$ day & $4^{\text {th }}$ day \\
\hline Hematocrit $(\%)$ & 40.3 & 42.8 & 45.1 \\
Platelets (x1,000) & 105 & 58 & 71 \\
Leukocytes (per ml) & 2,400 & 2,000 & 10,400 \\
TGP (Units) & $\mathrm{NP}$ & 429 & 830 \\
TGO (Units) & $\mathrm{NP}$ & 366 & 820 \\
\hline
\end{tabular}

NP: Not performed.

and agitation. The patient was hospitalized on the same day; on admission her blood pressure was $150 \times 100 \mathrm{mmHg}$ and axillary temperature was $38.4^{\circ} \mathrm{C}$. The patient exhibited abnormal behaviour, tremors of the extremities, seizures, myoclonal movements, bilateral grasping, and bilateral paratonous. An eye fundus examination gave a normal result. Computerized cerebral tomography revealed an intra-parenchymal calcification and cortico-subcortical atrophy that were unrelated to the effect of the dengue on the CNS.

\section{The surmmary of the main findings is given in the Table 2 .}

The patient's clinical state remained unaltered until June 11, when she presented a temporary loss of consciousness. Two days later she manifested precordial pain and became dyspneic; on the $12^{\text {th }}$ day of the disease her blood pressure dropped to $60 \times 40 \mathrm{mmHg}$ and central venous pressure was $24 \mathrm{~cm} \mathrm{H} \mathrm{H}_{2} \mathrm{O}$. Hepatomegaly and jugular turgescence were noted. The CSF was clear, with 10 cells $/ \mathrm{ml}$ (90\% lymphocytes) and $0.60 \mathrm{~g} / \mathrm{l}$ protein. Bacterioscopy and bacterial cultures of the CSF were negative. The neurological state suggested encephalitis. The patient developed shock with undetectable blood pressure and pulse, and died after cardiorespiratory failure.

Attempts to isolate the virus from the single serum sample obtained on the $4^{\text {th }}$ day of disease in C6/36 cells and by mouse brain inoculation were unsuccessful. The HI test was positive with titers $\geq 1,280$ for flaviviruses; the ELISA IgM was positive for dengue. In the NT, the serum sample neutralized DEN-1 $(>3.5 \mathrm{ILN})$ and DEN-2 (2.5 ILN).

The necropsy results revealed cerebral edema and encephalopathy. The patient was also diabetic and hypertensive.

\section{DISCUSSION}

Dengue hemorrhagic fever appears to be an immunological disease, generally resulting when a second dengue infection caused by a serotype different from that of the first infection occurs (HALSTEAD, 1988). There is, however, another hypothesis, which holds that the antigenic difference among strains of the different dengue virus serotypes is the main factor responsible for the pathogenesis of DHF during the course of epidemics (ROSEN, 1987). A Cuban research group has postulated that both factors, i.e. sequential infections (epidemiological factor) and great virulence of some strains (viral factor), plus individual risk factors (such as hypertension, chronic cardiac, pulmonary and/or metabolic diseases, and others) are responsible for the pathogenesis of DHF; this is the "integral hypothesis" (KOURI et al., 1989).

Currently there is sufficient epidemiological and experimental support to associate the sequential infection with the pathogenesis of DHF, especially when host related factors favour the disease outcome. This hypothesis suggests that the concentration of non-neutralizing antibodies developed after the first infection (primary response) enhances the viral activity in the mononuclear cells during the second dengue infection (secondary response). This phenomenon would be responsible for the initial pathophysiological changes that determine the terminal severity of the clinical state (HALSTEAD, 1981; 1988). It has recently been demonstrated in vitro that a cytotoxic factor is produced by peripheral blood leukocytes, and may play a role in the pathogenesis of DHF (MUKERJEE et al., 1995).

In Brazil, DHF cases have been reported mainly in adults (ZAGNE et al., 1994; VASCONCELOS et al., 1995). The factors responsible for the different target age group remain completely unknown. In Rio de Janeiro and Fortaleza, the two cities where DHF epidemics have been reported, almost all cases involved adult patients.

The present cases occurred in patients aged 17, 86, and 67 years, respectively. The factors associated with the pattern of clinical manifestations noted are still unclear. Various causes probably play a role in the development of DHF, and the interaction of these factors may be decisive in the development of the illness. Further studies, undertaken with the specific objective of defining these causes, are clearly needed and should be encouraged.

KOURY et al. (1989) reviewed the main findings during the 1981 epidemic in Cuba, including clinical data and autopsy results for 57 children and 27 adults: CNS involvement was not found or mentioned. We assume, therefore, that such involvement did not occur in the Cuban epidemic (KOURY et al., 1989).

Similarly, previous investigations in Indonesia, Thailand and other Asian countries have considered neurological involvement to be secondary to prolonged hemorrhagic fever, either with or without shock syndrome. The subsequent cerebral hemorrhage is not a result of the direct action of the virus on the CNS following breakdown of the blood-brain barrier (BHAMARAPRAVATI et al., 1967; SUMARMO et al., 1978; SUMARMO et al., 1983; PATEY et al., 1993).

An exhaustive study has been made of 100 fatal DHF cases in Thailand. CNS alterations were observed in only four cases in which subarachnoidal hemorrhage was found. The authors stressed that "frank neuronal necrosis, perivascular infiltration, and proliferation of glial cells were not observed" (BHAMARAPRAVATI et al., 1967). 
VASCONCELOS, P. F. C.; TRAVASSOS DA ROSA, A. P. A.; COELHO, I. C. B.; MENEZES, D. B.; TRAVASSOS DA ROSA, E. S.; RODRIGUES, S. G. \& TRAVASSOS DA ROSA, J. F. S. - Involvement of the central nervous system in dengue fever: three serologically confirmed cases from Fortaleza, Ceará, Brazil. Rev. Inst. Med. trop. S. Paulo, 40(1):35-39, 1998

However, the recent data of ROW et al., (1996) and LUM et al., (1996) suggest and partially support the idea that dengue viruses may be associated with neurological manifestation under certain circumstances. In these cases, however, such alterations are strongly indicative of a direct action of the virus on the brain structures, and not a consequence of hemorrhagic or metabolic disturbances. This evidence is compelling, as the DEN-3 virus was isolated from the CSF in four of the six patients examined, and was detected by PCR in another, while the DEN-2 virus was detected by PCR in the CSF of the sixth patient. Hence, a CNS injury compatible with encephalitis resulting from the direct action of the virus is strongly suggested by the demonstration of the DEN virus in the CSF (LUM et al., 1996). However, CHIMELLI et al. (1990) observed nonspecific morphological alterations in the brain of four patients from Niterói, Brazil, and in one the lesions were consistent with perivenous encephalitis. These five cases examined had a fatal outcome during the DEN-1 epidemic of 1987.

The dengue virus also has the capacity to infect cultured mouse neurons in vitro. The virus appears to have a specific receptor which resides exclusively on the surface of neurons, since astrocytes used in the same experiment are not infected (IMBERT et al., 1994). Other experimental studies in mice have demonstrated the breakdown of the blood-brain barrier (CHATURVEDI et al., 1991) during dengue infections. Such breakdown was seen after DEN-2 challenge, causing the leakage of protein into the brain; moreover the damage occurred in a dose-dependent manner.

As a consequence of the rapid increase in the immune response and the marked SR, it is difficult to isolate the DEN virus from the blood of patients as observed in the present study. All patients exhibited high levels of antibodies in blood samples taken at five, nine and ten days (case 1), nine days (case 2 ) and four days (case 3). The patients' clinical state plus the high level of HI antibodies against flaviviruses, the anti-dengue IgM positive by ELISA, and the positive neutralization tests suggest dengue virus as the etiologic agent.

It should be emphasized that this background probably contributed to the fatal outcome reported in the present study, should the Cuban hypothesis prove correct (KOURI et al., 1989).

PCR was performed on the serum sample with negative results (data not shown)

ZAGNE et al. (1994), discussed 56 DHF cases from Niterói, Rio de Janeiro State, Brazil with no findings of CNS involvement. In these cases, DHF was typically a hemorrhagic disease, with gum bleeding the most severe clinical manifestation. Similarly, in a dengue epidemic from Karachi, Pakistan, DHF was reported only in adults, without CNS involvement (CHAN et al., 1994).

With the increase in dengue infection in Brazil an important increase in the number of severe DHF cases, including the unusual CNS involvement observed in the present study, may occur. Genetic variation or a biological alteration in the virus may have taken place, and some strains may be responsible for the epidemics showing unusual clinical manifestation, including CNS involvement (ROSEN, 1977; GUBLER, 1996).

The possibility that such cases may occur during dengue epidemics should be kept in mind by physicians. The clinician must also be alert to the possibility of a dramatic change in prognosis in the first days of evolution, from a benign disease to one of fatal outcome.

\section{RESUMO}

Envolvimento do sistema nervoso central no dengue. Três casos confirmados sorologicamente em Fortaleza, Ceará, Brasil

Neste trabalho são descritos três casos de dengue com manifestações neurológicas incomuns durante a epidemia de dengue em Fortaleza, Estado do Ceará, em 1994. Todos os pacientes eram do sexo feminino. A paciente do primeiro caso tinha 17 anos e apresentou além da síndrome febril, sinais de comprometimento meníngeo com rigidez de nuca, e sangramento genital. No segundo caso a paciente de 86 anos apresentou quadro febril, intensa dor muscular e articular, alterações da consciência, desmaio, rigidez de nuca e meningismo. A terceira, de 67 anos, teve um quadro inicial de síndrome febril, seguida de comportamento anormal, tremores de extremidades, trombocitopenia, hematócrito aumentado, leucopenia, hipotensão arterial e choque, evoluindo para o óbito. Amostras sangüíneas obtidas das três pacientes foram negativas para tentativas de isolamento viral e apresentaram positividade por IH para Flavivirus (caso $1 \geq 1.280$; caso $2=320$; caso 3 $\geq 1.280$ ) e MAC ELISA para dengue, sendo negativas para outras doenças infecciosas como hepatites A, B e D, e leptospirose.

\section{ACKNOWLEDGEMENT}

We are grateful to Prof. Ralph Lainson for the English revision of the text.

\section{REFERENCES}

1. BHAMARAPRAVATI, N.; TUCHINDA, P. \& BOONYAPAKNAVIK, P. Pathology of Thailand haemorrhagic fever: a study of 100 autopsy cases. Ann. trop. Med. Parasit., 61: 500-510, 1967.

2. BEATY, B.; CALISHER, C. H. \& SHOPE, R. E. - Arboviruses. In: SCHMIDT, N. J. \& EMMONS, E., ed. Diagnostic procedures for viral, chlamydial and rickettsial infections. 6. ed. Washington, American Public Health Association, 1989. p. $797-855$.

3. CHAN, Y. C.; SLAHUDIN, N. I.; KHAN, J. et al. - Dengue haemorrhagic fever outbreak in Karachi, Pakistan, 1994. Trans. roy. Soc. trop. Med. Hyg., 89: 619620,1995

4. CHATURVEDi, U. C.; DHAWAN, R.; KHANNA, M. \& MATHUR, A. Breakdown of the blood-brain barrier during dengue virus infection of mice. $\mathbf{J}$. virol. Meth., 72: 859-866, 1991

5. CHIMELLI, L.; DUMAS HAHN, M.; BARRETTO NETTO, M. et al. - Dengue: neuropathological findings in 5 fatal cases from Brazil. Clin. Neuropath., 9: 157-16́2, 1990. 
VASCONCELOS, P. F. C.; TRAVASSOS DA ROSA, A. P. A.; COELHO, I. C. B.; MENEZES, D. B.; TRAVASSOS DA ROSA, E. S.; RODRIGUES, S. G. \& TRAVASSOS DA ROSA, J. F. S. - Involvement of the central nervous system in dengue fever: three serologically confirmed cases from Fortaleza, Ceará, Brazil. Rev. Inst. Med. trop. S. Paulo, 40(1):35-39, 1998

6. GUBLER, D. J. - The global resurgence of arboviral diseases. Trans. roy Soc. trop. Med. Hyg., 90: 449-451, 1996.

7. HALSTEAD, S. B. - The pathogenesis of dengue. Molecular epidemiology in infectious disease. Amer. J. Epidem., 114: 632-648, 1981.

8. HALSTEAD, S. B. - Pathogenesis of dengue: challenges to molecular biology. Science, 239: 476-481, 1988

9. IMBERT, J. L.; GUEVARA, P.; CASTANEDA, J. R. \& SOTELO, J. - Dengue virus infects mouse culture neurons but not astrocytes. J. Med. Virol., 42: 228$233,1994$.

10. KOURY, G. P.; GUZMÁN, M. G.; BRAVO, J. R. \& TRIANA, C. - Dengue haemorrhagic fever/dengue shock syndrome: lessons from the Cuban epidemic, 1981. Bull. WId. Hlth. Org., 67: 375-380, 1989

11. LUM, L. C. S.; LAM, S. K.; CHOY, Y. S.; GEORGE, R. \& HARUN, F. - Dengue encephalitis: a true entity? Amer J. trop. Med. Hyg., 54: 256-259, 1996.

12. MUKERJEE, R.; CHATURVEDI, U.C. \& DHAWAN, R. - Dengue virus-induced human cytotoxic factor: production by peripheral blood leukocytes in vitro. Clin. exp. Immunol., 102: 262-267, 1995.

13. PATEY, O.; OLLIVAUD, L.; BREUIL, J. \& LAFAIX, C. - Unusual neurologic manifestations occurring during dengue fever infection. Amer. J. trop. Med. Hyg., 48: 793-802, 1993

14. ROW, D.; WEINSTEIN, P. \& MURRAY-SMITH, S. - Dengue fever encephalopathy in Australia. Amer. J. trop. Med. Hyg., 54: 253-255, 1996.

15. ROSEN, L. - The Emperor's new clothes revisited, or reflections on the pathogenesis of dengue hemorrhagic fever. Amer. J. trop. Med. Hyg., 26: 337 343, 1977.
16. SHOPE, R. E. - The use of a microhemagglutination-inhibition test to follow antibody response after arthropod-borne virus infection in a community of forest animals. An. Microbiol. (Rio de J.), 11 (parte A): 167-171, 1963.

17. SUMARMO, H. W.; WULUR, H.; JAHJA, E. et al. - Encephalopathy associated with dengue infection. Lancet, i: 449-450, 1978.

18. SUMARMO, H. W.; JAHJA, E.; GUBLER, D. J.; SUHARYONO, W. \& SORENSEN, K. - Clinical observations on virologically confirmed fatal dengue infections in Jakarta, Indonesia. Bull. Wld. HIth. Org., 61: 693-701, 1983.

19. TESH, R. B. - A method for the isolation and identification of dengue viruses, using mosquito cell culture. Amer. J. trop. Med. Hyg., 28: 1053-1059, 1979.

20. VASCONCELOS, P. F. C.; MENEZES, D. B.; MELO, L. P. et al. - A large epidemic of dengue fever with dengue hemorrhagic cases in Ceará State, Brazil, 1994. Rev. Inst. Med. trop. S. Paulo, 37: 253-255, 1995.

21. WORLD HEALTH ORGANIZATION - Dengue haemorrhagic fever: diagnosis, treatment and control. Geneva, 1986

22. WORLD HEALTH ORGANIZATION - Dengue and dengue haemorrhagic fever in Venezuela. Dengue News Letter, 19: 33-34, 1995.

23. ZAGNE, S. M.; ALVES, V. G.; NOGUEIRA, R. M. et al. - Dengue haemorrhagic fever in the State of Rio de Janeiro, Brazil. Trans. roy. Soc. trop. Med., 88: 677$679,1994$.

Recebido para publicação em 13/01/1997 Aceito para publicação em 14/01/1998 
